\title{
Sorption properties of light hydrocarbon- contaminated clay under defined conditions
}

\author{
Judit Tóth \\ Department of Geology, \\ U niversity of Pécs, Pécs
}

\author{
Erika Knapp \\ U pstream Laboratories, EP IFA, \\ M OL PIc, Budapest
}

\begin{abstract}
Risk assessments and remediation plans of hydrocarbon-contaminated sites usually have been managed based on total petroleum hydrocarbon (TPH) content. Gasoline is one of the most mobile pollution agents, which consist mainly of light hydrocarbons. Measuring of TPH does not give enough information about the individual compounds. Another problem is using solvents such as nhexane for extraction. In some cases we would like to know about the hydrocarbon-adsorption properties of contaminated samples. The article describes a laboratory model for hydrocarbon contamination modeling, and measuring hydrocarbon sorption properties. For modeling the authors have chosen gasoline type hydrocarbon, homogeneous sand and clay samples from the Kiscell Clay Formation. Results of the modeling indicate that the referenced ATD-GC/MS method can be a very effective tool in the risk assessment of hydrocarbon-contaminated areas.
\end{abstract}

Key words: modeling, gasoline, sorption, clay, ATD-GC/MS

\section{Introduction}

Hydrocarbon contamination within the subsurface is very complex and in the environment it undergoes various physical, chemical and biological alterations (e.g. biodegradation, volatilization, adsorption, photolysis, hydrolysis and oxidation). The high mobility of light hydrocarbon explains why gasolines are the most serious risks for groundwater contaminations.

The most common approach to the measuring of the spilled hydrocarbon is based on gas chromatography and gas chromatography/mass spectrometry analyses. In Hungary, hydrocarbon-contaminated soil and groundwater at

Addresses: J. Tóth: H-7624 Pécs, Ifjúság útja 6, Hungary, e-mail: jtoth@gamma.ttk.pte.hu E. Knapp: H-1039 Budapest, Batthyány utca 45, Hungary, e-mail: eknapp@mol.hu Received: February 14, 2007; accepted: April 6, 2007 
exploration and production sites have been managed on the basis of their total petroleum hydrocarbon (TPH) content. Measuring of TPH contamination is not sufficient for the environmental and human health quantitative risk assessment, because it does not provide information about the compounds of the hydrocarbon-mixture (Tóth and Török 2006). The analyses of the aromatic compounds (BTEX and/or PAHs), as well as the biomarkers (particularly steranes and terpanes), provide useful information for the identification of the sources of hydrocarbon contamination. The distribution of n-alkanes, isoprenoid alkanes, the total concentration of the resolved peaks and the profile of the UCM (unresolved complex mixtures) indicate the degree of weathering. When the easily degraded normal hydrocarbons $\left(n-C_{17}\right.$ and $\left.n-C_{18}\right)$ are lost and the more degradation-resistant isoprenoids (pristane and phytane) conserved, this will result in a significant increase of the ratios of $\mathrm{Pr} / \mathrm{n}-\mathrm{C}_{17}$ and $\mathrm{Ph} / \mathrm{n}-\mathrm{C}_{18}$. For this reason these ratios have been widely used as indicators of oil biodegradation (Winters and Williams 1969; Wehner et al. 1988; Barakat 2001).

Usually in a crude oil we can measure heavier compounds rather than lighter ones, due to their easy volatilization. Another problem arises during extraction, when we use solvents such as n-hexane. Many publications have focused on gasoline contamination (e.g. Lahvis et al. 1999; Cunha and Leite 2000; Smallwood et al. 2002) but in the literature there are several definitions referring to the gasoline fraction. Gasoline is a complex mixture of a number of organic compounds including: alkanes (normal, branched and cyclo-), alkenes (normal, branched and cyclo-), alkylbenzenes, polynuclear aromatic hydrocarbons, elemental compounds and additives (Odermatt 1993). In most cases compounds with C5 to C8 (Whiticar and Snowdon 1999) or with iC5 to C8 (Obermajer et al. 2000) are included within the term gasoline range, but compounds containing C5 to $\mathrm{C} 10$ are also mentioned (Harris et al. 1999). Within the Hungarian petroleum industry the term gasoline refers to a special raw condensate which is a natural gas-based liquefied HC mixture, without any unsaturated components. In order to avoid misapprehensions rising from the different approaches we use term gasoline for our special hydrocarbon mixture and the term gasoline range for the C5-C8 components.

The carbon isotope ratios of individual hydrocarbons in the $\mathrm{C} 2-\mathrm{C} 8$ range provide reliable and unique information for oil correlation (Whiticar and Snowdon 1999). Comparison of chromatographic fingerprints from the pollutants with the materials in the storage tanks can be used to indicate possible origins of the spilled samples. Correlations are often poor if heavy weathering has occurred, because it generally leads to changes in the distribution of the volatile compounds in a groundwater/gasoline plume compared to the original sample in the tank.

Whilst the gas chromatograms of gasolines from two different tanks may be similar, the carbon isotopic fingerprint of the individual compounds may differ if the gasolines are derived from different suppliers (Smallwood et al. 2002). Thus 
geochemists prefer to focus on the isotopic signatures of the liquid and solid fractions while the evaporated components are investigated to a lesser degree.

In our model our aim is to follow closely the volatility of these light hydrocarbon components and to measure the adsorption characteristics of the clay. Minimizing sample transfer and evaporation during handling of samples requires a careful selection of analytical methods. We have given preference to the ATD-GC/MS method because of it does not require special sample handling, in addition to having other analytical advantages.

\section{$M$ aterials and modeling parameters}

For our modeling we employed specially constructed glass tubes (Fig. 1), liquid gasoline, gravel, homogeneous sand and clay. The tubes were installed in an isolated room at room temperature in order to provide standard circumstances during the modeling for thelong duration of the study. The $10 \mathrm{~cm}$-diameter tubes were equipped with a thin steel sieve directly below the filling material. We put $1413 \mathrm{~cm}^{3}$ liquid gasoline into the bottom of tubes and we left vapor space between the gasoline and the steel sieve. In this way only the volatilized compound could come into contact with the filling material; consequently, we could measure the volatile organic compounds in the sand and clay filling. Gravel beds were layered on the steel sieve, between vapor place and sand fill, in order to prevent the falling of sand grains into the liquid gasoline. Pairs of tubes of 50, 100, 150 and $200 \mathrm{~cm}$ height were filled with homogeneous sand. In addition a clay layer covered the sand in one tube of each pair. The tubes were open at the top.

Samples were taken from the liquid gasoline below the filling, from the vapor phase above the liquid gasoline, from the sand/clay filling and from the air above the filling. Samples from the gasoline were taken weekly in the initial period of the experiment; later, based on the results of the measurements, sampling was reduced to once monthly. Filling material was sampled after six and twelve months to determine the adsorptional features. Samples were taken from the homogeneous sand from every tube. In the case of the clay-capped tubes, both the clay and the sand below the clay were sampled.

Liquid and vapor samples were taken through the septums with liquid syringe and gas-tight syringe. Air space was sampled with air-space sampling equipment above the clay-cap. We took sand and clay samples with the help of an analytically pure spoon. Air space $(500 \mathrm{ml})$ and vapor $(100 \mu \mathrm{l})$ samples were measured immediately; liquid $(0.3 \mu \mathrm{l})$ and solid $(0.4 \mathrm{~g})$ samples were measured later. Gasoline, sand and clay were kept cool after sampling, and we left reference samples in glass phials in the laboratory refrigerator as well. Three parallel measurements from every sample were carried out without special sample handling; the average values were calculated from the parallel measurements.

Commercially available sand was used for modeling, because of its high homogeneity. Gravel for the gravel bed was also obtained commercially. 

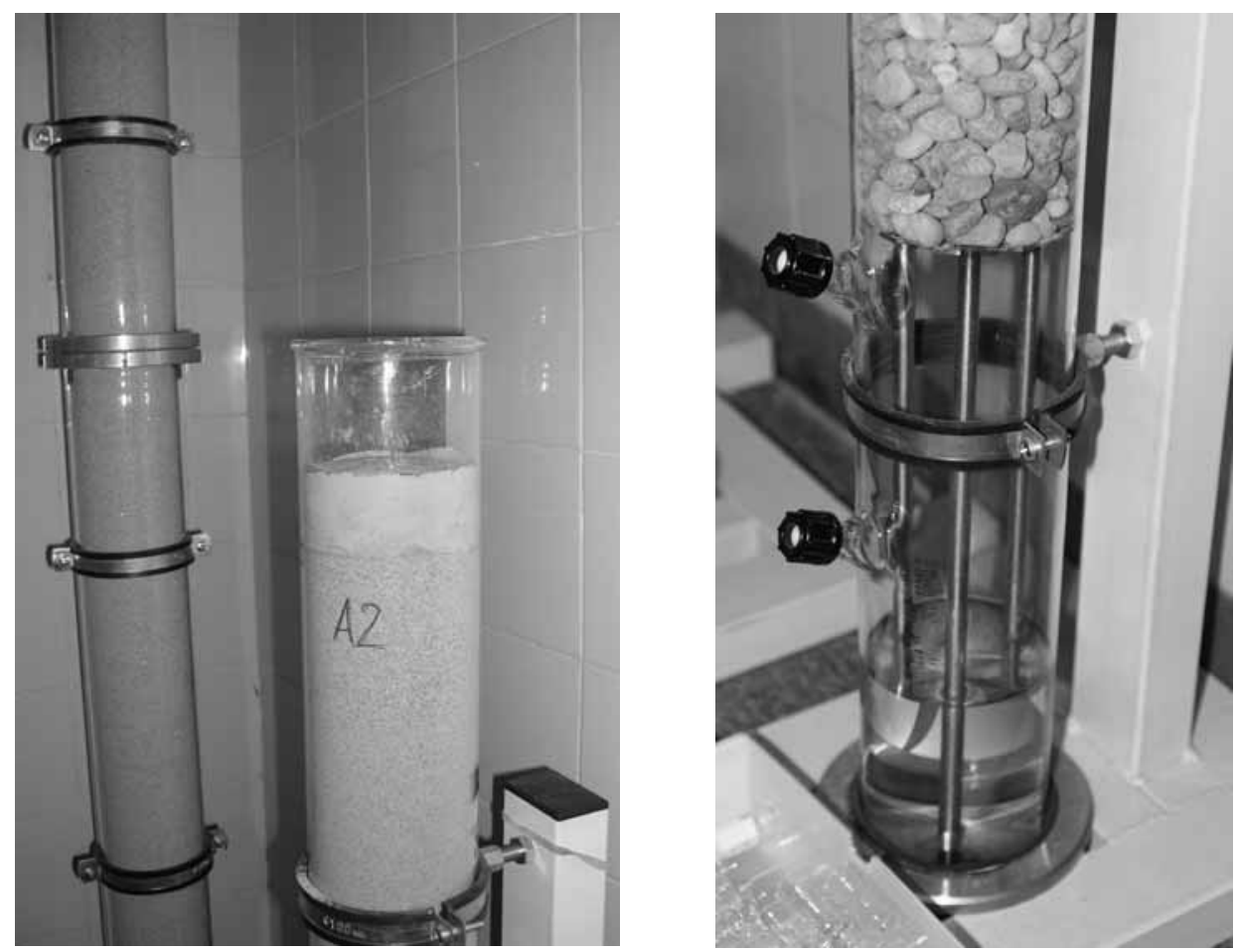

Fig. 1

Photos of the special glass tubes. The 100 and $150 \mathrm{~cm}$-high clay-capped tubes can be seen on the picture to the left. The picture to the right shows the bottom of a tube, with the gasoline, vapor place, sampling septums and gravel bed

Clay from the Kiscell Clay Formation was chosen as filling material, because this formation is well studied and widespread in the neighborhood of Budapest.

Two types of the clay were collected from the pit of the Wienerberger brickyard in Solymár. The Kiscell Clay Formation consists of homogeneous, fine grained, silty, clayey, carbonaceous layers which are grey, thick layered, often unstratified (Kalmár et al. 2003). One of the samples derived from this type of the formation while the other sample was collected from the oxidized, yellowish type of the formation. The detailed compositions of the material are shown later in the result and discussion chapter. Based on our analytical results the grey type of the clay was chosen for the modeling. 


\section{Analytical methods}

\section{ATD -GC/M S analysis}

Gas chromatographic analyses were carried out as the main analytical methods for determination and identification of the $\mathrm{HC}$ components in the experiment. The liquid and vapor phase were analyzed with a FISONS MEGA2 HRGC-type GC-FID apparatus. The analysis and the results of these two phases of samples are described elsewhere (Tóth and Kállai 2006; Tóth and Török 2006).

Samples from air space, sand and clay were measured with automatic thermodesorber-gas chromatograph/mass spectrometer. The technical data was as follows: A Gerstel TDSA2, A3 oven was programmed from $60^{\circ} \mathrm{C}(0$ mins) with $60{ }^{\circ} \mathrm{C} / \mathrm{min}$ ramp rate to $310^{\circ} \mathrm{C}$ ( $10 \mathrm{mins}$ ), standard measuring method, split mode, delay time of $0.5 \mathrm{~min}$, transfer temperature of $300{ }^{\circ} \mathrm{C}$; a CIS4 $\mathrm{CO}_{2}$-cooling, Carbotrap B adsorbent bed, oven was programmed from $-20{ }^{\circ} \mathrm{C}$ (0 min) with $12^{\circ} \mathrm{C} /$ min heat-up rate to $300^{\circ} \mathrm{C}$ ( 10 mins). Gas chromatography operated using the following: CIS split ratio set to $20: 1$, split $=8,7 \mathrm{ml} / \mathrm{min}$, pressure of $100 \mathrm{kPa}, \mathrm{He}$, total flow of $12.1 \mathrm{ml} / \mathrm{min}$ with constant flow measuring method, HP-PONA column (50 m length, $0.2 \mathrm{~mm}$ i.d., $0.5 \mu \mathrm{m}$ film thickness, $100 \%$ dimetil-siloxan); the gas chromatograph oven was programmed from $40^{\circ} \mathrm{C}(4 \mathrm{~min})$ with $10^{\circ} \mathrm{C} / \mathrm{min}$ ramp rate to $170{ }^{\circ} \mathrm{C}(1 \mathrm{~min})$, and to a final temperature of $300{ }^{\circ} \mathrm{C}$ with a $15 \mathrm{~min}$ hold time after a $60{ }^{\circ} \mathrm{C} / \mathrm{min}$ ramp rate. The MS detector technical data were: 1.2 min of solvent delay, scan $=33-550 \mathrm{amm}$, threshold $=150$, with scan measuring method $=2.85 \mathrm{scan} / \mathrm{s}$.

Filling material was sampled after six and twelve months to determine the adsorptional features. Three parallel measurements from the samples were carried out using ATD-GC-MS equipment with the same technical circumstances as mentioned above. Average values were calculated from the parallel measurements. The measurements were carried out with an admixture of $10 \%$ inert component in order to avoid the analyzing problems of the clay minerals.

\section{XRD analysis}

The mineralogical compositions of clay and sand were determined by X-ray diffraction analysis with a Philips 1820-type diffractometer, also at the MOL PIc. Upstream Laboratory. The technical data of measurements were the follows: $\mathrm{Cu}$ tube anod, start angle of $2^{\circ} 2 \Theta$, end angle of $70^{\circ} 2 \Theta$.

Thermal analysis, grain size distribution and carbonate content identification

As the volume of the clay may change during the heating process of the ATDGC/MS analysis, thermoanalytical, grain size-distribution and carbonate content measurements were performed to determine the main features. Thermoanalytical measurements for determination of clay mineral composition and 
water content of the clay were carried out with MOM-3434 type derivatograph$\mathrm{C}$ at the Mineralogical and Petrological Department, Geological Institute of Hungary. Grain size distribution was determined by Mastersize 2000 equipment at the Upstream Laboratory.

The carbonate content measurements were carried out with autocalcimeter (Geoservices type) at the Upstream Laboratory.

\section{Results and discussion}

Initial compositions

Hydrocarbon components to $\mathrm{C} 19$ could be identified in the gasoline below the filling materials in the initial period of the modeling. Based on the analytical results three groups could be distinguished according to the volatility of the components: highly volatile, less volatile and aromatic groups. Sixty-two\% of the measurable components proved to belong to the highly volatile groups, including $9 \%$ of aromatic hydrocarbons, while the residue $29 \%$ could be ranged into the less volatile group. The boundary between the highly and less volatile group could be drawn at octane, taking into consideration the analytical results gained during the experiment. Components to C39 were determined in all measurements because the gasoline was enriched in the less volatile components parallel with the escaping of the highly volatile types of HC from the system. Consequently C32 is present in measurable amounts after one year (Tóth and Kállai 2006).

In order to characterize the sand (commercial) and clay (Kiscell Clay Formation) used as filling material, grain size distribution analyses were performed. This is important because there is a connection between the surface areas of the samples and the adsorptive capacity.

In the sand the dominant grain size is between 0.1 and $1.0 \mathrm{~mm}$. The grain size distribution curve has two maxima: the first distribution between 0.282 and 0.632 $\mathrm{mm}$ with $0.91 \%$ shows a slight negative incline, while $99.09 \%$ of the sand (10-1000 m) has a symmetrical, peaky, bell-shape curve. The mode of this latter curve is $0.316-0.355 \mathrm{~mm}$ and the median is $0.334 \mathrm{~mm}$. Abundant quartz, less potassium feldspar, albite, and small amounts of dolomite and calcite were detected in the semiquantitative X-ray diffraction analyses. Muscovite, chlorite, kaolinite and amphibole are also present in trace amounts (Tóth and Kállai 2006).

Clay filling was investigated in more detail because greater difficulties can occur during the analyses, due to their swelling character. The grain size of the grey clay is between 0.0004 and $0.355 \mathrm{~mm}$, but the percentage of the larger grains (fraction above $0.100 \mathrm{~mm}$ ) is merely $1.85 \%$. The grain size distribution curve has one maximum, bell-shaped with a slight positive incline. The mode of the distribution is between 0.0063 and $0.00709 \mathrm{~mm}$ and the median is $0.00802 \mathrm{~mm}$. Semiquantitative X-ray diffraction analyses were carried out on both types of 
clay. Based on the analytical results the grey type was chosen for the modeling (Tóth and Kállai 2006).

In the semiquantitative X-ray diffraction analyses quart, muscovite, calcite, dolomite, chamosite, some nontronite and feldspar in traces could be detected. Results of the additional thermoanalytical investigations have indicated high amounts of montmorillonite $(11-22 \%)$, chlorite $(<12 \%)$ and calcite $(10 \%)$, less dolomite $(6 \%)$, goethite $(2 \%)$, detectable quantities of muscovite, quartz and amorphous phase, and illite in uncertain quantities as well.

The carbonate content measurement has indicated $10.8 \%$ carbonate content. This and the thermic properties of the clay were important for us because of the swelling character of the clay during chromatographic measurements. As mentioned the samples are heated up to $310^{\circ} \mathrm{C}$ during the ATD-GC/MS analysis, and the clay may loose adsorption water during chromatographic measurements that can cause technical problems in the equipment.

\section{A dsorptional characters of clay samples}

Adsorption of hydrocarbons on different materials has been reported by many previous studies, but most of them have measured fluid-mineral interactions. For fluids there are well-known adsorption isotherms. These isotherms were determined using the batch equilibration technique. The most frequently used models are those of Langmuir and of Freundlich, which describe the relationship between the adsorbed fluids and its equilibrium concentration.

Studies of hydrocarbon gases are less reported and the studies usually focus on adsorption of gases on coal, mainly methane adsorption in coal beds. Even less research has measured adsorption of gases on other materials, for example on clay minerals. Only a few studies measure adsorption capacities and adsorption selectivity of wet gases (Rodriguez et al. 1997; Volzone et al. 1999; Melnitchenko et al. 2000).

There are many publications about adsorption studies of polar organic and volatile organic compounds; some of them used clay minerals as adsorbents (Hinedi et al. 1993; Goss 1994, 1996; Donahue et al. 1999; Morrisey and Grismer 1999). However, only a few studies focus on gasoline sorption and even less on gasoline sorption on clays (e.g. Li and Gupta 1994). It is difficult to obtain information about volatilized hydrocarbon compounds in the literature, particularly if we would like to know more about of their sorption nature. Generally gasoline adsorption studies have reported on the liquid phase of gasoline and organoclay is used in the measurements as an adsorbent.

Organoclay can be created by exchanging the hydrated exchangeable cations of clay (usually bentonite) with various types of quaternary ammonium cations (Xu et al. 1997) or by other techniques (Srinivasan and Fogler 1990; Lo 1992). Due to the isomorphous substitutions in the aluminosilicate layers, natural clay minerals usually have a net negative charge, which is balanced by alkali metal 
and alkaline-earth-metal cations such as $\mathrm{Na}^{+}$and $\mathrm{Ca}^{2+}$. The strong hydration of these inorganic cations creates a hydrophilic environment on the surface and in the interlayer region of natural smectite clay (Souza Santos 1992). Organic molecules are hydrophobic, so they display no affinity with the hydrophilic surfaces of clay. The hydrophilicity of clay can be transformed into hydrophobicity when the exchange inorganic cations are replaced by quaternary ammonium cations in the form of $\left[\left(\mathrm{CH}_{3}\right)_{3} \mathrm{NR}\right]^{+}$or $\left[\left(\mathrm{CH}_{3}\right)_{2} \mathrm{NRR}\right]^{+}$. This replacement results in organophilic clay (Pereira et al. 2005).

The previous studies of gasoline adsorption have used X-ray diffraction analyses in general to illustrate the effect of increases of interlaminar distance in the clay samples' particles. Most of these studies do not show the same interactions between clay and hydrocarbons as between organoclay and hydrocarbons. For example, analytical results of ordinary bentonite mixed with gasoline do not show such a profound interlaminar increase, which suggests a lack of interaction between them (Gitipour et al. 2006). For modified bentonite samples, moderate increases (44.5\%) were observed in the unit cell thickness that support the hypothesis that organobentonite effectively intercalates gasoline hydrocarbons into its particles, thus increasing the clay's particle volume and thereby reducing soil permeability. For these reasons organoclay can be used as a viable material as a liner system for removing hydrocarbons at gasolinecontaminated locations (Gitipour et al. 2006). The mentioned results indicate that most of the former studies dealt with organoclay.

Organoclay is an artificial compound; consequently we cannot find organoclay at a gasoline-contaminated site prior to remediation. It would be interesting to know if it is really not possible to measure the interaction between natural clay minerals and gasoline compounds. There are some differences between our model and the natural environment. In order to simplify modeling conditions we have minimized the number of parameters in the model. It means that we have avoided the effect of water, interaction between liquid phase and filling material and changing of weather (e.g. temperature).

Quantitative and qualitative distributions of cations adsorbed in solid phase have a significant effect on the property of soil and can influence the hydrocarbon adsorption and mobility. In order to gain information about the ion exchange capacity of the Kiscell Clay Formation we have measured the cation exchange capacity (CEC) using Mehlich's method. With this method we could remove every exchangeable cation from soil samples (including the hydrogen ions as well). The basis of the method is to exchange the adsorbed cations of the soil with barium cations. In order to determine the CEC-value $\mathrm{Ba}^{2+}$ ions were pressed down by $\mathrm{Ca}^{2+}$ ions.

We have calculated CEC-value using the T-value (cation exchange capacity) equation of the MSZ-080212-78 standard. The CEC-value of our sand sample is $4,7336 \mathrm{meq} / 100 \mathrm{~g}$ and that of the clay sample is $33,1550 \mathrm{meq} / 100 \mathrm{~g}$. These values have shown how many cations can be adsorbed in exchangeable form by the 
samples used, and give the quantities of negative charges on the colloid's surfaces.

\section{M easured gasoline compounds in the filling material}

It has been possible to obtain useful information from superimposed chromatograms related to the hydrocarbon adsorption properties of the filling material. The clay adsorbed a part of the volatilized compounds, while the sand let them through. The adsorbed components represent a scale of the original composition. Clay fill has adsorbed the hydrocarbon components from C7 to C10 after six months. In the case of the 50 centimeter height tube adsorbed components from toluene to $\mathrm{C} 10$ predominated (Fig. 2). In taller tubes components up to $\mathrm{C} 9$ could be measured. After one year the scale of the detected components has expanded to C11 (Fig. 3). O-xylene, C9 components could also be measured in the clay samples after one year. In spite of the relatively high concentration and rapid volatilization of benzene from the liquid gasoline we could not measure benzene in the filling material. The high aromatic hydrocarbon contamination of the filling consists of toluene and xylenes. The superimposed chromatograms show that every sample represents the same scale from the original composition of the gasoline. In our opinion the scale ranges between $\mathrm{C} 7$ and $\mathrm{C} 12$. The modeling went on for more than one and a half years, which should be enough time for the volatile components to get through the coarse-grained sediments up to the clay in the $50 \mathrm{~cm}$-high tube.

We have compared the chromatograms of the clay, the sand below the clay and sand taken after six and twelve months from the tubes of the same height. Adsorbed components from C 7 to C11 predominated in all the clay-capped tubes. We have measured the same components in the clay and the sand below the clay, but in the case of the sand below clay they were in considerably lower quantities in the filling material. The lower quantities measured for in this case are due to th epresence of a clay cap. (Fig. 4). In the $50 \mathrm{~cm}$-high clay-capped tube the abundance of the peaks is ten times higher in the clay than the sand below the clay. We were unable to measure components in the sand-filled tubes with no clay caps. The different tubes show the same features as the $50 \mathrm{~cm}$-high tube.

We have assessed the quantities of contaminants (adsorbed hydrocarbons) using data from ATD-GC/MS analyses applying total peak areas (Figs 5, 6). Total peak areas gradually decrease toward the higher tubes; the least adsorbed components could be detected in the specimens from the highest ( $200 \mathrm{~cm}$-high) tube. Maximum quantities are limited by the quantities of volatilizated components. After half a year there was $950-1021 \mathrm{~cm}^{3}$ of liquid gasoline on the bottom of the clay-capped tubes and $887-997 \mathrm{~cm}^{3}$ in those tubes filled only with sand. After one year these quantities were $761-895 \mathrm{~cm}^{3}$ (clay-capped sand) and $714-879 \mathrm{~cm}^{3}$ (sand without clay cap). This points to the fact that after half a year a maximum of $463 \mathrm{~cm}^{3}$, and after one year a maximum of $652 \mathrm{~cm}^{3}$ of con- 
88 J. Tóth, E. Knapp

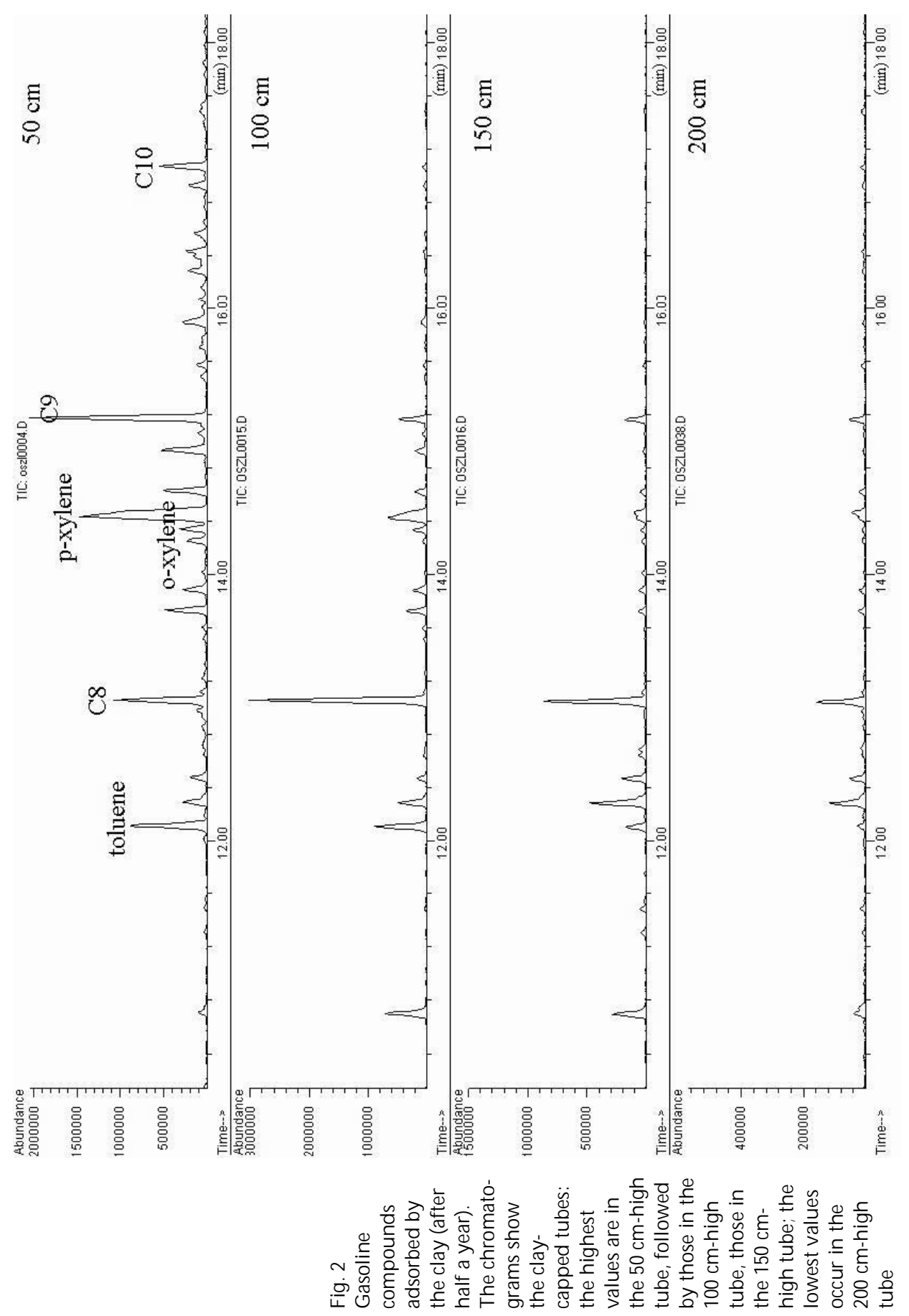

Central European Geology 50, 2007 
Sorption properties of light hydrocarbon-contaminated clay under defined conditions 89

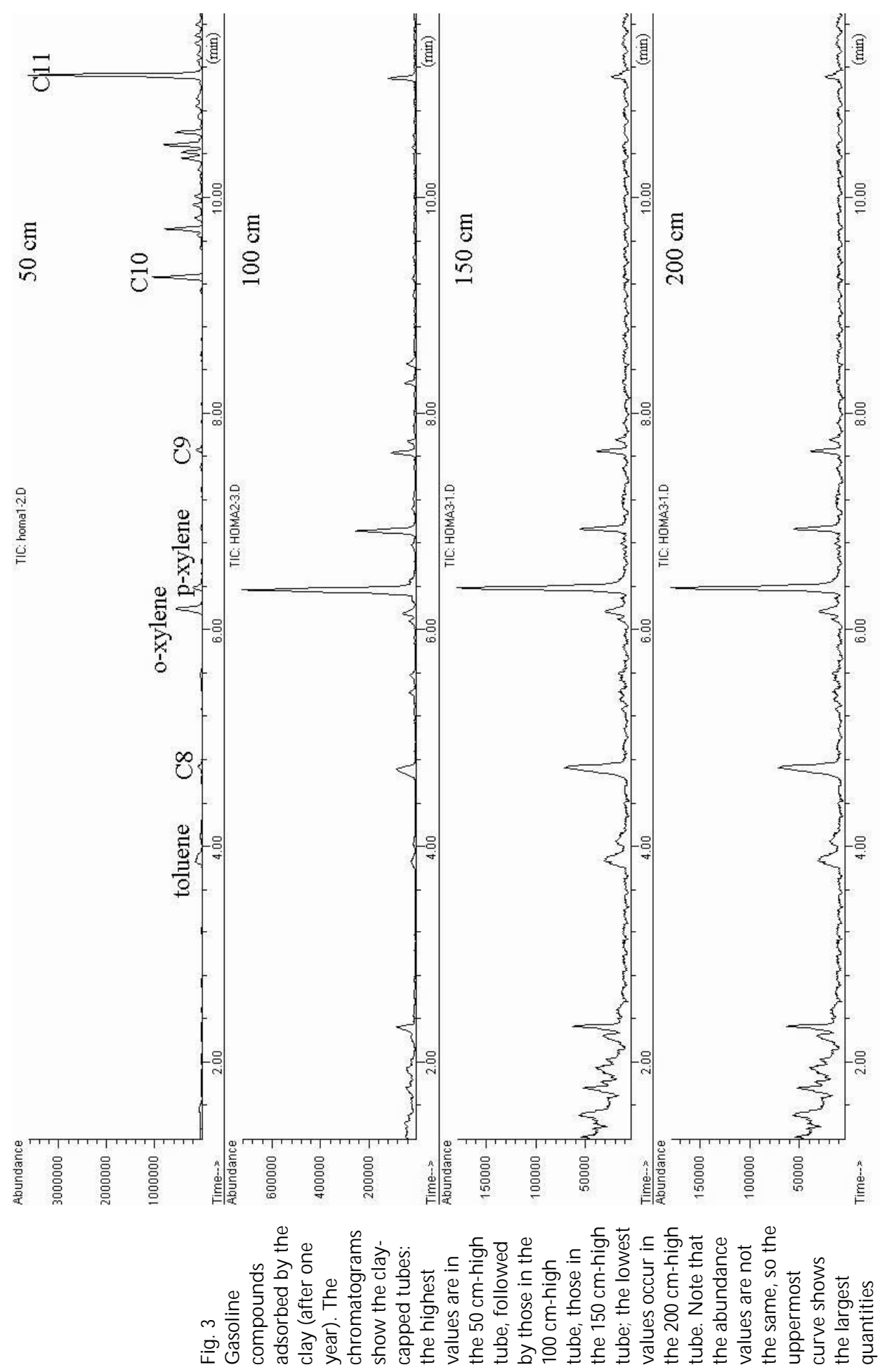


90 J. Tóth, E. Knapp
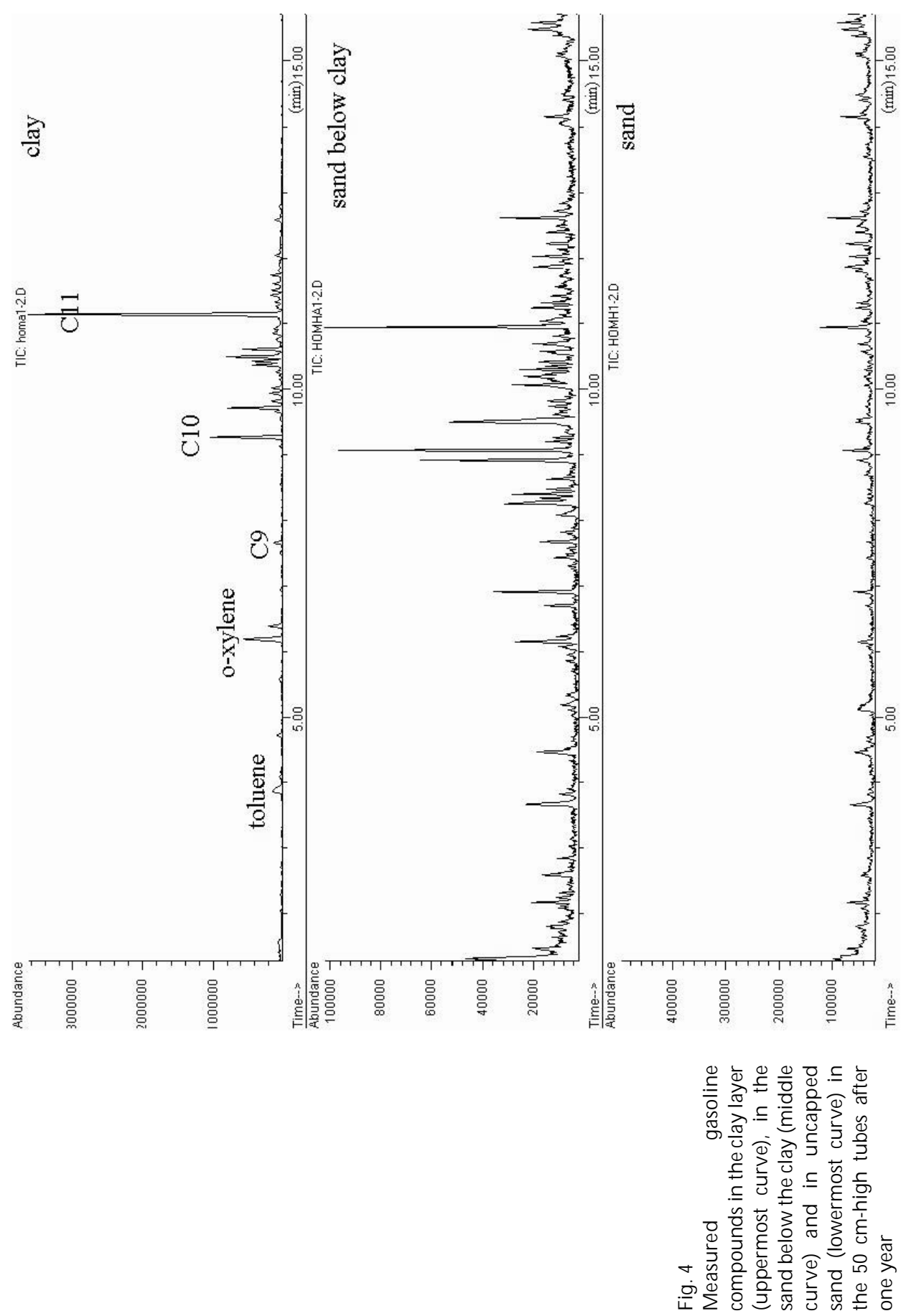

Central European Geology 50, 2007 
Fig. 5

Gasoline compounds adsorbed by the clay (after half a year)
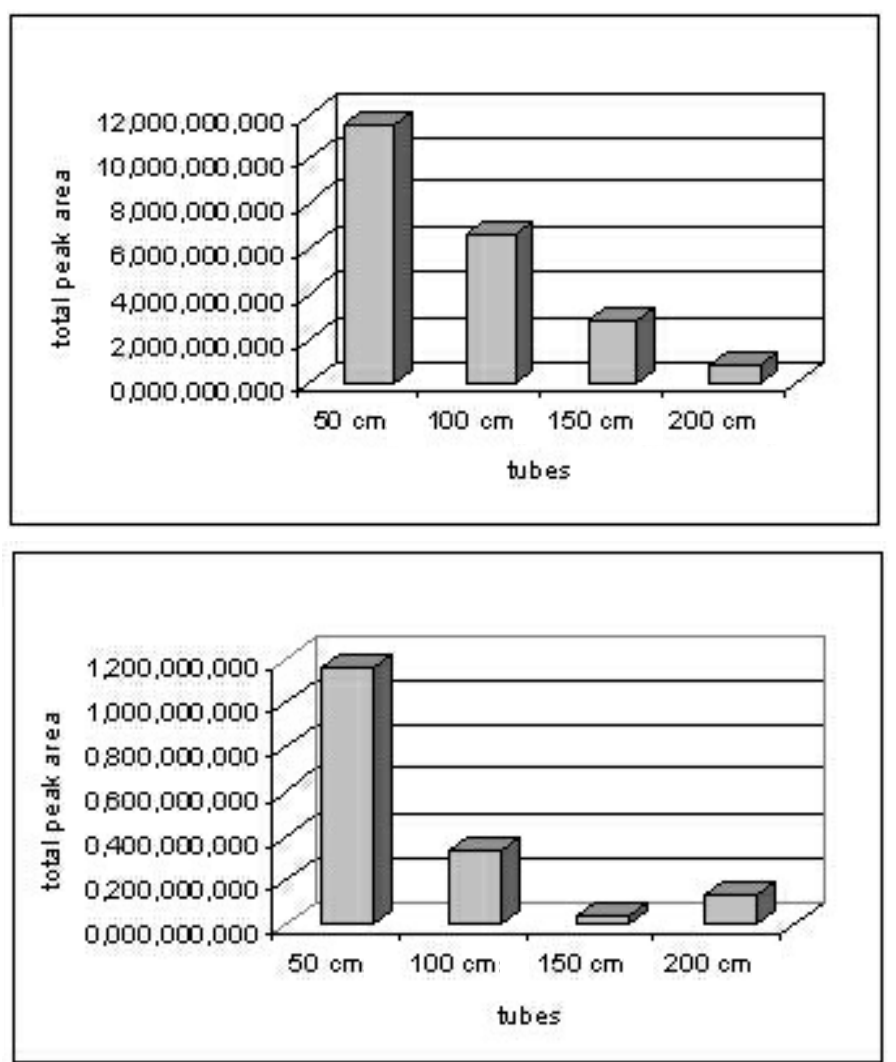

Fig. 6

Gasoline compounds adsorbed by the clay (after one year)

taminants could be present in every clay-capped tube, corresponding to the missing quantities of liquid gasoline. These are approximate values, however, because they are calculated for the total filling material, not only for the clay caps. Moreover many components could not reach the clay, or went out to the air (measured in air-space samples).

We have assessed quantities for components together and also one by one. Octane and nonane have a large total peak area after six months, but undecane has the largest after one year. Xylenes exhibit larger total peak areas than toluene in both time periods. Total peak areas of every aromatic hydrocarbon show strong correlation with the heights of tubes. The quantity of aromatic components decreases as the tube heights increase. This is similar for the other components, but without such a strong correlation.

\section{Conclusions}

In our model we attempted to closely follow the volatility of gasoline components and measure the adsorptional characters of the clay from the Kiscell Clay Formation. 
In order to minimize sample transfer and evaporation during handling of samples we gave preference to the ATD-GC/MS method because it does not require special sample handling, as well as having some other advantages. The measurements were carried out with an admixture of $10 \%$ inert component. With this admixture it is possible to avoid the analyzing problems of the swelling clay minerals (f.i. unstable pressure or equipment damage).

We have obtained useful information related to the hydrocarbon adsorption properties of the filling material. The clay adsorbed a part of the volatilized compounds, while the sand let them through. The adsorbed components represent a scale of the original composition from $\mathrm{C} 7$ to $\mathrm{C} 11$. We were unable to measure benzene in the filling material, in spite of the relatively high concentration and rapid volatilization of benzene from the liquid gasoline.

The relationship between the height of the tubes and quantities can influenced by the means of transport. In order to gain information about the means of transport and to carry out a mass balance, it was decided to analyze the filling material from the liquid fraction to the top of the filling.

Results of the modeling indicate that the ATD-GC/MS method can be a very effective tool in the risk assessment and remediation planning of hydrocarboncontaminated areas. Many secondary effects (e.g. biodegradation, solubility) can significantly modify a GC signature, which also suggests the use of detailed chromatographic analyses supplementing the TPH-analyses.

\section{Acknowledgements}

The authors gratefully acknowledge MOL PIc USL Manager Tibor Ördög for permission to conduct their research. We would like to recognize the significant contributions of Dr. Ernõ Török, Dr. Mariann Kállai, Andrea Lukács (MOL Plc USL) and Dr. Tibor Szederkényi (University of Pécs). We also appreciate the assistance of the MOL Plc USL staff in making measurements (Dr. Éva Váradi, Mrs. Mária Németh, Ernõ Balogh) and of Dr. Mária Földvári (Geological Institute of Hungary) for the thermoanalytical investigation. We thank Dr. Tibor Németh and an anonymous reviewer for helpful comments and suggestions.

\section{R eferences}

Barakat, A.O., Y. Qian, M. Kim, M.C. Kennicutt 2001: Chemical characterization of naturally weathered oil residues in arid terrestial environment in Al-Alamein, Egypt. - Environment International, 27, pp. 291-310.

Cunha, C.D., S.G.F. Leite 2000: Gasoline biodegradation in different soil microcosms. - Brazilian Journal of Microbiology, 31, pp. 45-49.

Donahue, R.B., S.L. Barbour, J.V. Headley 1999: Diffusion and adsorption of benzene in Regina clay. - Can. Geotech. J./Rev. can. geotech., 36/3, pp. 430-442.

Gitipour, S., A. Baghvand, S. Givehchi 2006: Adsorption and permeability of contaminated clay soils to hydrocarbons. - Pakistan Journal of Biological Sciences, 9/3, pp. 336-340. 
Goss, K.U. 1994: Adsorption of organic vapors on polar mineral surfaces and on a bulk water surface; development of an empirical predictive model. - Environmental Science and Technology, 28, pp. 640-645.

Goss, K.U. 1996: Adsorption of VOCs from the gas phase to different minerals and a mineral mixture. - Environmental Science and Technology, 30, pp. 2135-2142.

Harris, S.A., M.J. Whiticar, M.K. Eek 1999: Molecular and isotopic analysis of oils by solid phase microextraction of gasoline range hydrocarbons. - Organic Geochemistry, 30, pp. 721-737.

Hinedi, R., C.T. Johnston, C. Erickson 1993: Chemisorption of benzene on Cu-montmorillonite as characterized by FTIR and 13C MAS NMR. - Clays and Clay Minerals, 41, pp. 87-94.

Kalmár J., G. Szurkos, P. Kovács-Pálffy 2003: Üledékképzõdés és kõzettéválás a dél-budai Kiscelli Agyag Formációban, a IV. sz. metró nyomvonalán mélyült fúrásokban (Sedimentation and lithification in the Kiscell Clay Formation from South Buda, in the boreholes deepened in the pathway of the (projected) IVth Metro Line). - MÁFI Évi Jelentése, 2000-2001, pp. 107-119.

Lahvis, M.A., A.L. Baehr, R.J. Baker 1999: Quantification of aerobic biodegradation and volatilization rates of gasoline hydrocarbons near the water table under natural attenuation conditions. Water Resources Research, 35/3, pp. 753-765.

Li, Y., G. Gupta 1994: Adsorption of hydrocarbons by clay minerals from gasoline. - Journal of hazardous materials, 38/, pp. 105-112.

Lo, I.M.C. 1992: Development and evaluation of clay-liner materials for hazardous waste sites. Ph.D. Dissertation, The University of Texas at Austin. - In: Lake, C.B., R.K. Rowe 2005: A comparative assessment of volatile organic compound (VOC) sorption to various types of potential GCL bentonites. - Geotextiles and Geomembrans, 23, pp. 323-347.

Melnitchenko, S., J.G. Thompson, C. Volzone and J. Ortiga 2000: Selective gas adsorption by metal exchanged amorphous kaolinite derivative. - Applied Clay Science, 17, pp. 35-53.

Morissey, F.A., M.E. Grismer 1999: Kinetics of volatile organic compound sorption/desorption on clay minerals. - Journal of Contaminant Hydrology, 36, pp. 291-312.

MSZ-08-0215-78: Hungarian standard for determination of the cation adsorption capacity of the soil, Modified Mehlich technique.

Obermajer, M., K.G. Osadetz, M.G. Fowler, , L.R. Snowdon 2000: Light hydrocarbon (gasoline range) parameter refinement of biomarker-based oil-oil correlation studies: An example from Willistone Basin. - Organic Geochemistry, 31, pp. 959-976.

Odermatt, J.R. 1993: Natural chromatographic separation of benzene, toluene, ethylbenzene and xylenes (BTEX compounds) in a gasoline contaminated ground water aquifer. - Organic Geochemistry, 21/10/11, pp. 1141-1150.

Pereira, K.R. de O., R.A. Hanna, M.M.G. Ramos Vianna, C.A. Pinto, M.G.F. Rodrigues, F.R. Valenzuela Diaz 2005: Brazilian organoclays as nanostructured sorbents of petroleum-derived hydrocarbons. - Material Researches, 8/1, pp. 77-80.

Rodriguez, M.A., J. Rubio, M.J. Liso, J.L. Oteo 1997: Application of inverse gas chromatography to the study of the surface properties of slates. - Clays and Clay Minerals, 45, pp. 670-680.

Smallwood, B.J., R.P. Philp, J.D. Allen 2002: Stable carbon isotopic composition of gasolines determined by isotope ratio monitoring gas chromatography mass spectrometry. - Organic Geochemistry, 33/2, pp. 149-159.

Souza Santos, P. 1992: Science and Technology of Clays. 2rdsd. São Paulo, Edgar Blucher, 1992, 3 v. (in Portuguese). - In: Ramos Vianna, M.M.G., J.H.R. Franco, C. A. Pinto, F.R. Valenzuela Diaz, P.M. Büchler 2004: Sorption of oil pollution by organoclays and a coal/mineral complex. Brazilian Journal of Chemical Engineering, 21/2, pp. 239-245.

Srinivasan, K.R., H.S. Fogler 1990: Use of inorgano-organo-clays in the removal of priority pollutants for industrial wasteaters: Structural aspects 38, pp. 277-286. - In: Lake, C.B., R.K. Rowe 2005: A comparative assessment of volatile organic compound (VOC) sorption to various types of potential GCL bentonites. - Geotextiles and Geomembrans, 23, pp. 323-347.

Tóth, J., M. Kállai 2006: Gazolin szennyezõdés laboratóriumi modellezése (Laboratory modelling of gasoline contamination). - Földtani kutatás, 58/3, pp. 1-12. 
94 J. Tóth, E. Knapp

Tóth, J., E. Török 2006: Geochemistry-based modelling of hydrocarbon contamination. - European Geologist, 22, pp. 32-35.

Volzone, C., J.G. Thompson, A. Melnitchenko, J. Ortiga, S.P. Palethorpe 1999: Selective gas adsorption by amorphous clay-mineral derivatives. - Clays and Clay Minerals, 47, pp. 647-657.

Wehner, H., M. Teschner, K. Bosecker 1988: Bakterieller Abbau als mögliche Ursache für die Entstehung von Schwerölen. - Erdöl und Kohle - Erdgas - Petrochemie vereinigt mit Brennstoffchemie, 41/3, pp. 107-112.

Whiticar, M.J., L.R. Snowdon 1999: Geochemical characterization of selected Western Canada oils by C5-C8 Compound Specific Isotope Correlation (CSIC). - Organic Geochemistry, 30/9, pp. $1127-1161$.

Winters, J.C., J.A. Williams 1969: Microbiological alteration of crude oil in the reservoir. - In: Symposium on petroleum transformation in geologic environments. Div. Pet. Chem. Am. Chem. Soc. New York, Sept. pp. 7-12, Paper PETR 86, E22-E31.

Xu, S., G. Sheng, S.A. Boyd 1997: Use of organoclays in pollution abatement. Advances in Agronomy, 59, pp. 25-62. - In: Lake, C.B., R.K. Rowe 2005: A comparative assessment of volatile organic compound (VOC) sorption to various types of potential GCL bentonites. Geotextiles and Geomembrans, 23, pp. 323-347. 